\title{
WHAT THE ‘OLD GUYS’ CAN TELL US: EDWARDS AND BELL'S THE THEORY AND MEASUREMENT OF BUSINESS INCOME
}

\author{
Geoffrey Whittington \\ Emeritus Professor, CFPA, Judge Business School, Cambridge, England
}

\begin{abstract}
*
In this article, Geoffrey Whittington reflects on the contribution of Edwards and Bell to the accounting literature. The paper suggests that the issues that Edwards and Bell addressed still underlie many of the contemporary debates, such as that on the conceptual framework of financial reporting. Edwards and Bell (1961) is not only an important historical document but also highly relevant to current thought and practice, and worthy of much better integration within the current accounting literature.
\end{abstract}

\section{INTRODUCTION}

When I was asked to write about a piece of accounting literature that had particularly interested me, the choice was instantaneous and inevitable: Edwards and Bell. Their book, first published by the University of California Press in 1961, has become a legend in the accounting literature, widely cited and very influential but, as with many legends, more often cited than closely studied. The date of publication was particularly apt, coming at the beginning of the golden decade of a priori accounting theory that saw the publication of seminal work by Chambers

\footnotetext{
* Author's Note: This paper is a response to the editors' invitation to write about the piece of accounting literature that has influenced me most. The decision to write about Edwards and Bell was made before the sad news of Philip Bell's death, although that event made the choice more poignant. Philip Bell was a good friend and colleague, as well as an outstanding contributor to accounting thought.

Editors' Note: This paper is the first of an occasional series where influential academicians are invited to reflect on an accounting literature which in turn influenced them. The purpose is to explore aspects of the accounting traditions which are significant in the formation of accounting thought and practice as represented by the author and to introduce this literature to a new generation of scholars and students of accounting.
} 
Whittington

(1966), Gynther (1966), Sterling (1970) and others, all of whom were concerned centrally with the problem of measurement in financial reporting. Thus, in its first decade, Edwards and Bell was much cited and had a significant impact on accounting thought. It also had a significant impact on accounting practice during the brief reign of current cost accounting (CCA) in the late 1970s and early 1980s. Current cost operating profit was essentially the same concept as Edwards and Bell's preferred measure of current operating profit, although attempts by standard setters to adjust for general inflation by means of gearing adjustments and monetary working capital adjustments within a CCA framework were not consistent with the Edwards and Bell system, as the authors made clear in their introduction to the Garland reissue of the book (1995). They preferred to deal with general inflation by means of general price level adjustments, to obtain consistent measures in real terms.

Inevitably, interest in Edwards and Bell's work declined with the growth of interest in empirical studies in accounting research and the associated loss of interest in 'normative' theory, which occurred with increasing momentum in the 1970s. Equally, the interest of accounting standard setters and other policy makers declined after the withdrawal of current cost accounting in the 1980s. Edwards and Bell subsequently became a popular footnote reference, referring to the past rather than to current concerns: hence the predominance of citation over close study. Symptomatic of this was a fairly recent discussion on measurement between the present author and a very distinguished American accounting academic: when Edwards and Bell was cited as the source of an argument, the American academic responded, 'gee, these are old guys. I don't have to read that stuff!' Hence, the title of this paper.

As a result of this change of fashion, Edwards and Bell were never given the AAA (American Accounting Association) award for notable contributions to accounting literature, although they were belatedly admitted to the Accounting Hall of Fame (in 2003). Apart from personal considerations, this is unfortunate for the development of the accounting discipline, because the issues that Edwards and Bell addressed still underlie many of the contemporary debates, such as that on the conceptual framework of financial reporting.

\section{EDWARDS AND BELL'S THEORY}

Edwards and Bell approached their work as economists, which was their primary background, although the book contains an extremely thorough account of how the theory could be applied in practical accounting systems, complete with extensive journal entries. The great strength of the book is in its marrying of theory and practice by the sound application of principles derived from the economics of the firm to the problem of accountability. ${ }^{1}$ The basic theory is stated in chapters 2 to 4 of the book. The starting point is that the firm is a profit-seeking entity and that the role of the financial accounts is to trace the firm's progress in achieving that end in an uncertain world. Ex ante subjective value (the discounted present value of expected future cash flows) drives decisions relating to the firm but expectations 
are not reliable enough for financial accounting. The measures used in accounts have to be based on objective ex post transactions, events and market prices. Within this framework ex post income measures are seen as useful summary measures of progress towards realising subjective value, or, as the authors express it, the process of turning subjective goodwill into objective goodwill.

The complexity of the problem of measuring the economic progress of a business means that there is a variety of alternative income measures that can be useful. Each of the income measures proposed by Edwards and Bell articulates clearly with the balance sheet; the aggregate income measure being consistent with changes in net assets in the balance sheet. In this respect, the Edwards and Bell approach is consistent with the 'balance sheet' approach adopted in the International Accounting Standards Board's (IASB) framework, and with the comprehensive income approach to measuring performance that is currently being developed by the IASB. However, the Edwards and Bell approach also emphasises the importance of income measures and attaches particular importance to the disaggregation of the income statement into sub-components that reflect different sources of gain or loss.

Two important dimensions of income are separated. These are, respectively, gains accruing over time and gains resulting from use in operational activities. The former are described as holding gains and the latter as operating gains. They are both components of income but they represent different sources of gain (or loss). The context is assumed to be a manufacturing firm, where the distinction between operations (manufacturing) and holding (stocks and fixed assets) is most clear; the position is more complicated in, for example, a financial institution whose operations include taking a position on price changes.

Having separated operating activities from holding activities, the next step is to define clearly the income of the period. Here the authors make the very important observation that realised income, which is the traditional basis used in historical cost accounting, includes the holding gains and losses of prior periods that are realised in the current period. The separation of holding from operating gains and the correct allocation of holding gains to the period enables a correct assessment of periodic income. This correct allocation is made by carrying the assets and liabilities at current value, which causes holding gains and losses to be recognised immediately the price change occurs, rather than on subsequent realisation, and thus avoiding the recognition of holding gains when they are realised (as in historical cost accounting) rather than when the value change occurs (as in current value accounting). The result of this is a two-part income statement, the first part of which shows current operating profit or loss (current revenue less current costs, where 'current' implies prices current in the period) and the second shows current holding gains and losses ('current' implying gains and losses arising from price changes that occurred in the period).

The next issue to be resolved is how to measure the current values on which holding gains are based. Edwards and Bell define two alternatives: current acquisition costs, described as entry values, and current realisable values, described as exit values or opportunity costs. It is acknowledged that both have a degree of relevance, but entry values are preferred for a going concern business, 
Whittington

because they represent the current cost of resources available to be used in future operations. Such holding gains are described as realisable cost savings and the measure of profit that adds these to operating profit is known as business profit. The alternative measure of holding gains based on exit values (opportunity cost) is regarded as less relevant in a going concern manufacturing business because the assets are held for use rather than for sale in their present state. When the opportunity cost basis is used to measure holding gains and operating profit, the resulting total is described as realisable profit. It is recognised that the realisable profit measure is useful as a short-run measure of profit, showing whether the return from exit at opportunity cost at the end of the accounting period (a liquidation value) would have justified entry at opportunity cost at the beginning of the period. However, this is not the main consideration for going concern operations and, for such entities, Edwards and Bell prefer operating profit measured on an entry value basis (the operating profit component of business profit) as the key measure of performance. This profit measure shows the extent to which the current sales revenue exceeds the current cost of goods sold and is therefore a measure of the economic sustainability of the production process. Operating profit needs to be sufficient to provide an acceptable return on the current cost of the net assets used in production if replacement is to be justified; hence its characterisation as a long-run profit measure. The excess of expected operating surpluses over the cost of capital, defined by Edwards and Bell as excess realisable profit, is the source of subjective goodwill. ${ }^{2}$

The final distinction between the income measures that are proposed by Edwards and Bell is that between money income and real income, the latter being money income translated into real terms by being adjusted for general price level changes. They rightly point out that the primary problem is to record current prices at a common date for all individual assets and liabilities. Not only are these specific prices an important source of information in their own right (capturing the effects of relative price changes in money measures of income) but they facilitate the translation of money income into real income; once all items are recorded in money values established at a common date (and therefore in currency units of the same date), comparisons in real terms with values established at another date can be achieved merely by general index adjustment of the aggregate. This type of adjustment is, of course, particularly important in periods of high and variable inflation, and it is therefore not surprising that Edwards and Bell was widely cited in the inflation accounting debates of the 1970s and early 1980s (Tweedie and Whittington, 1984). Adjustment for inflation using general indices had been explored extensively by earlier writers, notably, in the English language, by Henry Sweeney (1936), who had also demonstrated the possibility of combining current (as opposed to historical cost) valuations with general index adjustment. ${ }^{3}$ However, Edwards and Bell made a unique contribution by emphasising the primary requirement to adjust for specific price changes (current values), with general index (real terms) adjustment as useful additional information (especially in periods of high and variable inflation), rather than as the primary problem of price change accounting. Furthermore, in the second part of their book, Edwards and Bell developed a simple and elegant 
series of closing adjustments that would enable their system to be implemented without compromising the historical cost accounting records of the reporting entity.

\section{THE CURRENT RELEVANCE OF EDWARDS AND BELL}

Enough has been said to indicate that, in the past, Edwards and Bell's book has had a significant impact on accounting thought and practice, but why should we still study 'these old guys'?

For at least three reasons:

1. Insofar as their work underlies current thought and practice, we need to go back to the original source in order to achieve a proper understanding. Just as geometers still study Euclid, so accountants should study Edwards and Bell.

2. Some of their work is relevant to current issues in thought or practice but its lessons have been forgotten, or never learned by a generation that has been taught to ignore 'old guys'.

3. Insofar as their work is imperfect or incomplete (as is almost inevitable), ironing out the imperfections or completing the picture are tasks that should challenge the current researcher.

It is perhaps insufficient to enunciate these reasons ex cathedra, especially as the object of this paper is to attract the interest of those who have previously ignored Edwards and Bell's work, so the remainder of the paper is devoted to providing examples of each of the three types of case. In most cases, the ideas will also be found elsewhere in the accounting literature, but Edwards and Bell wove them into a unique theoretical framework and expressed them with a clarity and insight that repays study: 'what oft was thought but ne'er so well expressed'.

\section{Embodiment in Current Thought and Practice}

One of the most hotly debated issues in current financial reporting is the form of the income statement, and, in particular, the idea that it should be a comprehensive income statement, articulating with the balance sheet. Articulation, sometimes referred to as the 'clean surplus' relationship, requires that comprehensive income, less capital contributions from equity and less payments to equity, is equal to the change over the period in the amount of equity recorded in the balance sheet. This concept underlies the theory of Edwards and Bell, and their preferred concept of business profit. They explain both the mechanics and the underlying theoretical justification of comprehensive income measures with a clarity that has been achieved rarely, before or since 1961. Their income statement was divided into two sections: an operating profit measure and a statement of holding gains (realisable cost savings, using 
Whittington

their preferred entry value measurement), the two components summing to a comprehensive income measure (business profit, on the entry value basis). An early attempt to apply a similar (but not identical) format in accounting standards was the ASB's FRS 3 (first issued in October 1992) (Accounting Standards Board, 1992), which presented a comprehensive income measure, total gains, in two statements, the first including a measure of operating profit (together with some other items) and the second (the Statement of Recognised Gains and Losses, or STRGL) adding in other recognised gains and losses to yield total gains. ${ }^{4}$ The IASB has also recently adopted a comprehensive income format (Revision of IAS 1: Presentation of Financial Statements, 2007). Hence, Edwards and Bell's fundamental insight that there should be a statement of comprehensive income, with separate disclosure of operating profit and other gains and losses, has made a significant impact on financial reporting practice.

An unresolved issue relating to this is the issue of subtotals within the comprehensive income statement, and particularly the definition of operating profit. Edwards and Bell's operating profit is similar in concept to the earnings figure that many preparers of accounts have advocated in their submissions to the IASB. A study of the Edwards and Bell concept and the theoretical case supporting it should illuminate the present debate. It would show the limitations of such a figure, as well as its possible strengths, and might also suggest restrictions on what should be included in it. ${ }^{5}$

A particular insight of Edwards and Bell relating to income statement presentation is their emphasis on identifying income of the period and separating the effects of holding gains and losses made in prior periods which are included in the realised gains recorded in historical cost measures of income. Although full current value accounting is necessary to achieve this fully, it is surely helpful within a mixed measurement system to separate out those current value gains that do clearly represent gains of the period from historical cost gains that may represent the realisation of gains accruing over a number of periods. Such a distinction was proposed by an unpublished International Accounting Standards Committee (IASC) advisory committee report and is still one of the issues to be considered in the IASB/FASB (International Accounting Standards Board/Financial Accounting Standards Board) project on reporting financial performance.

In addition to the obvious relevance of Edwards and Bell to reporting financial performance, their treatment of price change accounting is still relevant to practice and to current accounting standards. Their analysis of general price level adjustment, including a demonstration of how such adjustments can be made at the end of each accounting period, thus preserving the historical cost record, is consistent with the current international standard on accounting in hyperinflationary economies (IAS 29) but much clearer and better grounded in theory. Their message that such adjustments are best made when the individual items are measured at a common date is also an important one which should be heeded when IAS 29 is revised or if a new general standard on price change accounting is developed. ${ }^{6}$ 
Edwards and Bell's The Theory and Measurement of Business Income

\section{Relevance to Current Issues}

As a work of accounting theory, the most obvious relevance of Edwards and Bell is to the current development of a joint IASB/FASB conceptual framework for financial reporting. This new framework seems likely to influence the development and interpretation of accounting standards for many years to come. There are two important lessons that can be learned from Edwards and Bell in this context. First, the understanding of the setting in which financial reporting takes place, and second, the specific implications of this for the measurement debate, which is often characterised as the fair value question.

The IASB and FASB have exposed for comment, as the first stage of their revised joint conceptual framework, a discussion paper containing their preliminary views on the objectives of financial reporting (IASB, 2006). This would have been enhanced by taking account of the analysis of Edwards and Bell, who dig deeper into the fundamental reporting process and its relationship with the profit maximising objective. The current framework documents talk extensively about the need for financial accounting data to aid the prediction of future cash flows, but they lack Edwards and Bell's clarity in establishing the precise nature of this relationship. Edwards and Bell analyse accounting as an ex post process, reporting past transactions and events, whereas future cash flows are ex ante estimates, representing subjective goodwill and are not suitable for incorporation in financial reports. Therefore, accounting data can usefully show past and current progress towards achieving future targets and, in the process, can provide feedback to investors or managers that will be relevant to their decisions, but they do not attempt to provide complete information for decisions, by anticipating all relevant future events. Such elements as operating profit, for example, may be useful initial inputs to a model for predicting future operating cash flows (with additional assumptions about future trends in sales and margins), but they will not, by themselves, provide a complete assessment of 'subjective goodwill'. Thus, Edwards and Bell view the reporting process as accountability or stewardship, based on past transactions and events, rather than a direct source of predicting future cash flows. ${ }^{7}$ The removal of stewardship as a distinct objective of financial reporting was one of the more controversial aspects of the first chapter of the discussion draft of the new conceptual framework. ${ }^{8}$

The implications for measurement of the Edwards and Bell approach are also at variance with the current IASB/FASB approach in the conceptual framework revision project ${ }^{9}$ because, unlike the IASB and FASB, they do not aspire to identify a single ideal method of measurement. Rather, they see merit in a variety of valuation methods and income measures. Their preferred measure of business income is based on current replacement cost, but they are careful to demonstrate the potential usefulness of opportunity cost for some purposes. In particular, this is the case when an asset is surplus to operational requirements and is held for sale that will realise opportunity cost. ${ }^{10}$ This eclectic approach arises from their basic model, which recognises the fundamental uncertainty of the environment in which financial reporting takes place, and the role of financial reports in reducing, but not eliminating, that uncertainty by providing an objective account of the 
Whittington

entity's progress to date. Their approach can be classified as an information approach rather than a measurement approach (Beaver and Demski, 1979; Hitz, 2007): they view accounting as providing useful information to be fed into models of valuation or decision making, rather than providing direct measurements of discounted cash flows or other economic phenomena.

\section{Gaps and Limitations}

It would be misleading to suggest and unrealistic to expect that Edwards and Bell, writing in 1961, had the final answer to all of the problems in the field of business income measurement. However, the limitations of their work should provide a starting point for their successors, and failure to understand those limitations would lead to misuse of their insights.

An obvious limitation of their work was that they assumed a standard productive firm which was a going concern. Hence, the preference for entry value measurement could be justified by the need for assets to be used in production and ultimately replaced. Edwards and Bell reverted to the 'opportunity cost' (exit) value only for 'short-run' profit measurement and in the case of assets that were to be sold as being surplus to requirements. However, in the case of a firm engaged in investment rather than production, the case for the replacement assumption is less persuasive, and the availability for sale of the assets strengthens the case for opportunity cost measurement.

The assumption of a firm that had productive operations also minimised the operational difficulties of separating holding gains from operating gains. This is a plausible dichotomy and would be very informative where it could be made precisely, and, to achieve this, Edwards and Bell made the arbitrary assumption that production was instantaneous. In reality, all production takes time, so that there is a degree of arbitrariness in allocating between operating profits and holding gains. ${ }^{11}$ This problem becomes acute when input prices fluctuate widely and when the 'operational' element is difficult to define. That is why non-manufacturing firms fit less easily into the framework. Financial companies are a good example of the possible ambiguity of the operating/holding distinction. Holding financial instruments for gain may be a central part of their operational skills, and this challenges the relevance of the distinction between holding gains that occur as a result of price changes over time and operating gains that occur as a result of a production process. This is why the income presentation problems of financial institutions will receive special consideration at a later stage of the IASB/FASB project on reporting financial performance.

The practicality and usefulness of the operating/holding distinction are essentially empirical issues. A more fundamental limitation of the Edwards and Bell model is the time horizon. The business profit model assumes a going concern, which implies an indefinite and possibly infinite life for the entity. Thus, it seems likely that, to justify continuation, subjective goodwill will be positive at the end of any accounting period and it may be larger than it was at the beginning of the period because of new opportunities that have arisen during the year. 
The assumption of indefinite life may seem to contradict Edwards and Bell's algebraic and numerical illustrations in chapter 2 of their book, 'Core of the Theory', which demonstrate how subjective goodwill is realised and converted to market value over the finite life of a firm or investment. ${ }^{12}$ In reality, new investments will take place continuously and expectations about the returns to existing investment (and therefore the value of subjective goodwill) will change. Thus, over a realistically indefinite horizon, there will be no exact correspondence between realised and subjective profit: the closing position will always include an element of unrealised subjective goodwill. However, the illustrations over a finite life do serve to illustrate the relationship between ex post accounting measures and ex ante expectation measures: they are misleading only if it is not understood that, for an indefinite time horizon, the relationship is not an exact one for a whole entity. ${ }^{13}$

In evaluating the performance of a going concern business, Edwards and Bell's preferred measure is the operating profit component of business profit. This shows the extent to which current revenue exceeds the current cost of inputs and can provide a foundation for predicting future operating profits ${ }^{14}$ and therefore for estimating subjective goodwill. The holding gain elements of business profit (realisable cost savings) will also need to be taken into account in making future predictions, but these will be more difficult to model because, by their nature, they are likely to be unpredictable. The usefulness of the Edwards and Bell holding gain information for predictive purposes was not explored deeply in the book and is still a subject worthy of further research. An unfortunate consequence of the decline of interest in Edwards and Bell's work is that it has been substantially ignored in the extensive discussions of James Ohlson's important work (Ohlson, 1995) on the relationship between accounting information and stock market valuation. Ohlson's model provides an alternative dichotomisation of income (into permanent and transitory components) which might nevertheless be consistent with the Edwards and Bell model in some conditions: both models are derived from the residual income model originally identified by Preinreich (1938).

A further significant aspect of Edwards and Bell that might be regarded as incomplete is the important and topical question of measurement. ${ }^{15}$ The book acknowledges that both exit and entry values may be useful in different circumstances which define the likely disposition of the asset by a profitmaximising business: replacement costs are seen as most relevant to items that are to be replaced. One issue here is the definition of replacement cost in circumstances of technical change. Edwards and Bell preferred replacement with identical items, whereas recent literature and applications have preferred the 'modern equivalent asset' approach. ${ }^{16}$ One of the original authors (Edwards, 1975) subsequently expressed doubts about the original argument but concluded that the issue was not easily resolved. The authors also later espoused deprival value as being a clearer framework within which to justify the use of replacement cost (Edwards and Bell, 1995), but deprival value itself is still being evolved and debated (Stark, 1997; Van Zijl and Whittington, 2006). Thus, clarification is still required of the definition of and the precise case for using replacement cost. 
Whittington

\section{CONCLUSION}

This has been a brief and rather superficial review of Edwards and Bell's work. A book of such importance can be appreciated properly only in its full original form. However, it is hoped that the author has fulfilled the basic purpose of the paper, which is to persuade the reader that Edwards and Bell is not only an important historical document but also highly relevant to current thought and practice, and worthy of much better integration within the current accounting literature. The 'old guys' are still well worth reading.

\section{ACKNOWLEDGEMENTS}

The author is grateful to the editors of the journal and to Eamonn Walsh for comments on an earlier draft, but any remaining deficiencies are the responsibility of the author.

\section{NOTES}

1 The present paper, together with the majority of the subsequent literature that refers to Edwards and Bell, concentrates on external accountability, particularly to investors. The authors also stressed the value of their system for internal accountability to management. Management would have an explicit future plan or budget based on inside information, against which to evaluate ex post performance. Management's evaluation task would therefore be easier than that of the external user, whose assessment of 'subjective goodwill' is necessarily less well informed.

2 Chapter 2, Appendix B.

3 Chapter 3 of Sweeney's book demonstrates how current values can be combined with general index adjustment, and also illustrates the separation of realised from unrealised gains. However, the chapter is very short and Sweeney did not emphasise this aspect of his work, preferring to concentrate on general price level adjustments. In a conversation with Philip Bell in the 1980s the present author was told that Edwards and Bell were unaware of the contents of Sweeney's chapter 3, although they cited his work as a standard reference on general price level adjustment ('stabilised accounting').

$4 \quad$ FRS 3 assumes the current mixed measurement methods used in current accounting standards and so does not yield the same measures as Edwards and Bell's business profit statement, but the basic aim of distinguishing operating gains from other gains and presenting a 'clean surplus' comprehensive income measure is present in both.

5 Some of the complexities involved in defining a concept of operating profits or earnings are explored in Barker (2004).

6 The international standard, IAS 15 (1981), now withdrawn, was an extremely permissive document, reflecting the lack of consensus on the subject at the time of its issuance. It merely recited the broad approaches available, in very general terms, and expressed no preference or requirement.

7 This argument is elaborated in Whittington (2008).

8 A revised version of the preliminary views on this part of the conceptual framework was published as an exposure draft in May 2008. 
9 Details of the current state of this, and other IASB projects, can be found on the IASB website: <http://www.iasb.org/Current+Projects/intro.htm>.

10 In relation to the current debate on fair value, it should be noted that Edwards and Bell's opportunity cost is not the same as fair value (as defined in SFAS 157, 2006), because it represents the realisable proceeds, net of selling costs, rather than the selling price.

11 Kay (1977), in a review of the Sandilands Report (1975), gave the vivid example of the price of gold changing whilst a gold watch was being manufactured.

12 This result depends upon cash realisation at termination. This is the assumption used by Kay (1976), Peasnell (1982) and others to demonstrate the relationship, over the life of an investment, between the accounting rate of return and the internal rate of return. In the introduction to the 1995 re-issue of their book, Edwards and Bell acknowledge that Preinreich (1936, 1937 and 1938) anticipated their theoretical demonstration of the relationship between subjective (expected) and objective (realised) goodwill in a finite horizon context.

13 It will be exact for particular projects that have terminated by the end of the period, but a going concern entity will have uncompleted projects that have associated subjective goodwill.

14 This is discussed in Revsine (1973), chapters 4 and 5.

15 Stevenson (2007) provides a recent evaluation of Edwards and Bell's relevance to the current measurement debate in financial reporting.

16 See Byatt (1986), Sandilands (1975) and Edwards, Kay and Mayer (1987). The FASB standard, FAS 33 (1979), and the Accounting Standards Committee (ASC) standard, SSAP 16, all advocate economic cost of replacement of the service rather than the specific asset.

\section{REFERENCES}

Accounting Standards Board (ASB) (1992). FRS 3: Reporting Financial Performance, London: Accounting Standards Board.

Accounting Standards Committee (ASC) (1980). SSAP 16: Current Cost Accounting, London: Accounting Standards Committee.

Barker, R. (2004). Reporting Financial Performance, Accounting Horizons, Vol. 18, No. 2, pp. 157-172.

Beaver, W. and Demski, J. (1979). The Nature of Income Measurement, The Accounting Review, Vol. 54, No. 1, pp. 38-46.

Byatt, I.C.R. (1986). Accounting for Economic Costs and Prices: A Report to HM Treasury by an Advisory Group (the Byatt Report), 2 volumes, London: HMSO.

Chambers, R.J. (1966). Accounting, Evaluation and Economic Behavior, Englewood Cliffs, NJ: Prentice Hall.

Edwards, E.O. (1975). The State of Current Value Accounting, The Accounting Review, Vol. 50, No. 2, pp. 235-245.

Edwards, E.O. and Bell, P.W. (1961). The Theory and Measurement of Business Income, Berkeley, CA: University of California Press.

Edwards, E.O. and Bell, P.W. (1995). The Theory and Measurement of Business Income, reprinted with a new introduction, New York, NY and London: Garland Publishing.

Edwards, J.S.S., Kay, J.A. and Mayer, C.P. (1987). The Economic Analysis of Accounting Profitability, Oxford: Clarendon Press.

Financial Accounting Standards Board (FASB) (1979). FAS 33: Financial Reporting and Changing Prices, Norwalk, CT: FASB. 
Whittington

Financial Accounting Standards Board (FASB) (2006). SFAS 157: Fair Value Measurements, Norwalk, CT: FASB.

Gynther, R.S. (1966). Accounting for Price-Level Changes: Theory and Procedures, Oxford: Pergamon Press.

Hitz, J.-M. (2007). The Decision Usefulness of Fair Value Accounting: A Theoretical Perspective, European Accounting Review, Vol. 16, No. 2, pp. 323-362.

International Accounting Standards Board (IASB) (2006). Preliminary Views on an Improved Conceptual Framework for Financial Reporting: The Objective of Financial Reporting and Qualitative Characteristics of Decision-Useful Financial Reporting Information, London: IASB.

International Accounting Standards Board (IASB) (2007). Revision of IAS 1: Presentation of Financial Statements, London: IASB.

International Accounting Standards Committee (IASC) (1981). IAS 15: Information Reflecting the Effects of Changing Prices, London: IASC.

International Accounting Standards Committee (IASC) (1989). IAS 29: Financial Reporting in Hyperinflationary Economies, London: IASC.

Kay, J.A. (1976). Accountants, too, Could be Happy in a Golden Age: The Accountants Rate of Profit and the Internal Rate of Return, Oxford Economic Papers, Vol. 28, No. 3, pp. 447-460.

Kay, J.A. (1977). Inflation Accounting: A Review Article, The Economic Journal, Vol. 87, June, pp. 300-311.

Ohlson, J. (1995). Earnings, Book Values and Dividends in Equity Valuation, Contemporary Accounting Research, Vol. 11, No. 2, pp. 661-687.

Peasnell, K.V. (1982). Some Formal Connections Between Economic Values and Yields and Accounting Numbers, Journal of Business Finance and Accounting, Vol. 9, No. 3, pp. 361-381.

Preinreich, G.A.D. (1936). The Fair Value and Yield of Common Stock, The Accounting Review, Vol. 11, No. 2, pp. 130-140.

Preinreich, G.A.D. (1937). Valuation and Amortization, The Accounting Review, Vol. 12, No. 3, pp. 209-226.

Preinreich, G.A.D. (1938). Annual Survey of Economic Theory: The Theory of Depreciation, Econometrica, Vol. 6, No. 3, pp. 219-241.

Revsine, L. (1973). Replacement Cost Accounting, Englewood Cliffs, NJ: Prentice Hall.

Sandilands, F.E.P. (1975). Inflation Accounting: Report of the Inflation Accounting Committee Under the Chairmanship of F.E.P. Sandilands, Cmnd. 6225, London: HMSO.

Stark, A.W. (1997). The Impact of Irreversibility, Uncertainty and Timing Options on Deprival Valuations and the Detection of Monopoly Profits, Accounting and Business Research, Vol. 28, No. 1, pp. 40-52.

Sterling, R.R. (1970). Theory of the Measurement of Enterprise Income, Lawrence, KS: University Press of Kansas.

Stevenson, K.M. (2007). Fair Value: The Right Measurement Basis? An Australian Perspective, in P. Walton (ed), The Routledge Companion to Fair Value and Financial Reporting, London and New York, NY: Routledge.

Sweeney, H.W. (1936). Stabilized Accounting, New York, NY: Harper.

Tweedie, D.P. and Whittington, G. (1984). The Debate on Inflation Accounting, Cambridge: Cambridge University Press.

Van Zijl, A. and Whittington, G. (2006). Deprival Value and Fair Value: A Reinterpretation and a Reconciliation, Accounting and Business Research, Vol. 36, No. 2, pp. 121-130.

Whittington, G. (2008). Fair Value and the IASB/FASB Conceptual Framework Project: An Alternative View, Abacus, Vol. 44, No. 2, pp. 139-168. 